\title{
Effects of antibacterial compound of Saccharomyces cerevisiae from koumiss on immune function and caecal microflora of mice challenged with pathogenic Escherichia coli 08
}

\author{
Yujie Chen ${ }^{1,2}$, Chen Aorigele ${ }^{2}$, Chunjie Wang ${ }^{3}$, Wenqian $\mathrm{Hou}^{2}$, \\ Yunsheng Zheng ${ }^{1}$, Huasai Simujide ${ }^{2}$ \\ Inner Mongolia Agricultural University, ${ }^{1}$ Vocational and Technical College, Baotou, \\ ${ }^{2}$ College of Animal Science, Hohhot, ${ }^{3}$ College of Veterinary Medicine, Hohhot, Inner Mongolia, China
}

Received July 21, 2018

Accepted April 23, 2019

\begin{abstract}
The yeast Saccharomyces cerevisiae from koumiss has been shown to have antibacterial effects on Escherichia coli, possibly by producing antibacterial compound in metabolism; however, there is limited knowledge about its application in animal production. We therefore investigated the effects of an antibacterial compound of $S$. cerevisiae from koumiss on the immune function and caecal microflora of mice challenged with pathogenic Escherichia coli O8. Three groups were formed: negative control (NC), positive control (PC), and the antibacterial compound of $S$. cerevisiae at $\mathrm{pH} 2.0(\mathrm{~S} 2)$. Mice in the NC and PC groups were orally administered phosphate buffer solution (PBS) for $7 \mathrm{~d}$. At $4 \mathrm{~d}, E$. coli O8 was administered intraperitoneally in group PC. Mice in group S2 were first administered orally as mice in group NC, and subsequently intraperitoneally administered E. coli $\mathrm{O} 8$ as mice in group PC. Compared with the NC group, mice in the PC group displayed clinical symptoms and pathological changes in the small intestine. Small intestine villi in the S2 group also developed some histologically pathological changes but not as severe as in the PC group. Moreover, there was less mortality in the S2 group than in the PC group. In PC group, thymus indexes, immunoglobulin A (IgA) in serum and Bifidobacterium in caecum were decreased and $E$. coli in the caecum was increased. In the S2 group, CD8+ of T lymphocyte subsets in blood and Bifidobacterium in caecum were decreased, while spleen indexes, IgG, IgM in serum, and CD3+ of T lymphocyte subsets in blood were increased. This suggests that $\mathrm{S} 2$ can relieve clinical symptoms of mice challenged with pathogenic E. coli $\mathrm{O} 8$, enhance their immune function, and influence their caecal microflora. The study will provide a theoretical foundation for utilizing antibacterial compound of $S$. cerevisiae from koumiss for curative purposes.
\end{abstract}

Clinical symptom, pathological change, immunoglobulin, lymphocyte subsets

Koumiss is a traditional beverage made from unpasteurized fresh mare milk fermented by yeasts and other microorganisms, and has beneficial influences on treating several diseases, such as cardiovascular disease, digestive disease, tuberculosis, diabetes and diarrhea (Montanari et al. 1996; Ishii and Konagaya 2002). Previous studies revealed that Saccharomyces cerevisiae is one of the major species in koumiss in Inner Mongolia and Xinjiang, China (Quan et al. 2006; Mu et al. 2012). It was reported that $S$. cerevisiae has antibacterial effects on Escherichia coli possibly by producing antibacterial compounds, such as organic acids and killer toxin during metabolism (Etienne-Mesmin et al. 2011). However, the physiological properties and metabolic performances of yeasts form different sources varied (Csoma et al. 2010; Lane et al. 2011). Recently, probiotics of Saccharomyces, such as live yeasts, yeast cell walls, and yeast cultures have gradually been applied in animal production (Swanson et al. 2002a,b; Chiquette 2009). So far, there has been limited knowledge on the application of antibacterial compounds of $S$. cerevisiae from koumiss in animal production. 
Pathogenic E. coli are common pathogens in animal husbandry. Clinical symptoms and pathological changes of various animals after infection differ. For example, pathogenic $E$. coli often result in diarrhea in calves, leading to high morbidity and mortality. Carriers of pathogenic $E$. coli are the sources of infection; their excreta contact the feed, water, grassland, resulting in enormous economic losses for the breeding industry (Boerlin et al. 1999; Gow et al. 2008; Mainda et al. 2015).

Antibiotics are used in calves in treating diarrhea due to pathogenic E. coli, but excessive use and abuse of antibiotics results in drug resistance of many pathogenic E. coli; moreover, antibiotic residues in animals may endanger human health and safety (Cizman 2003; Levy and Marshall 2004; Tadesse et al. 2012; Dwivedi et al. 2015). Therefore, new alternative methods to treat or prevent $E$. coli infections, such as probiotics from koumiss, are being investigated. In our previous study, we isolated many pathogenic E. coli from calve rectum faeces in the Hulunbeier area of Inner Mongolia, China. Among these strains, $E$. coli $\mathrm{O} 8$ was the dominant pathogenic strain (Simujide et al. 2012). In addition, we found that an antibacterial compound of $S$. cerevisiae from koumiss could inhibit the growth of pathogenic E. coli $\mathrm{O} 8$ in vitro (Chen et al. 2015). It is expected to become a new antibiotic substitute. Hence, in the present study, mice were orally administered the antibacterial compound of $S$. cerevisiae by gavage, and comparative experiments were conducted after mice were challenged with pathogenic E. coli O8. The effects of the antibacterial compound of $S$. cerevisiae from koumiss on the immune function and caecal microflora of mice challenged with pathogenic $E$. coli $\mathrm{O} 8$ were determined. The study provides a theoretical foundation for utilizing the antibacterial compound of $S$. cerevisiae from koumiss in practice.

\section{Materials and Methods}

\section{Reagents and strains}

The reagents and strains used were as follows: Potato dextrose (PD) liquid medium (BD, NewYork, USA). Antibodies: monoclonal rat anti-mouse CD3:fluorescein isothiocyanate (FITC) (11-0032), monoclonal rat anti-mouse CD4:phycoerythrin (PE) (12-0041), monoclonal rat anti-mouse CD8:PE (12-0081), monoclonal rat anti-mouse CD19:FITC (11-0193) (Affymetrix, California, USA). Escherichia coli O8: the dominant pathogenic E. coli isolated from calve rectum faeces in the Hulunbeier area of Inner Mongolia, China (Simujide et al. 2012). The virulence gene of $E$. coli $\mathrm{O} 8$ was eaeA and classified as atypical enteropathogenic E. coli (EPEC). Escherichia coli $\mathrm{O} 8$ was thawed, subcultured onto a nutrient broth medium (BD, New York, USA), and harvested following $24 \mathrm{~h}$ of incubation at $37^{\circ} \mathrm{C}$. The growth phase was a log phase according to its growth curve (Chen et al. 2017).

Saccharomyces cerevisiae: the major yeast isolated and identified in koumiss samples collected from the Hulunbeier area was grown in PD liquid medium (potato $300 \mathrm{~g} / 1$, dextrose $20 \mathrm{~g} / 1$, chloramphenicol $0.1 \mathrm{~g} / 1$ ), and harvested following a $72 \mathrm{~h}$ incubation at $25^{\circ} \mathrm{C}$. The culture solution was filtered, then the antibacterial compound of S. cerevisiae was extracted by ethyl acetate at $\mathrm{pH}$ 2.0, according to Chen et al. (2015) (S2). The main components were found to be citric $(6595.90 \mathrm{mg} / 100 \mathrm{~g})$, ascorbic $(1157.53 \mathrm{mg} / 100 \mathrm{~g})$, lactic $(971.03 \mathrm{mg} / 100 \mathrm{~g})$, malic $(778.12 \mathrm{mg} / 100 \mathrm{~g})$, and formic $(768.27 \mathrm{mg} / 100 \mathrm{~g})$ acids, and killer toxin $(70.99 \mathrm{mg} / 100 \mathrm{~g})(\mathrm{Chen}$ et al. 2017).

\section{Animal and experimental design}

A total of 96 mice of the Kunming strain obtained from the Animal Centre of Inner Mongolia University, Hohhot, China, weighing 18-22 g were randomly divided into 3 groups of 32 mice each. The experimental design is presented in Table 1 (Chen et al. 2015). Mice in each group were reared in conventional cages $(545 \times 395 \times 200 \mathrm{~mm})$ with sawdust maintained at a constant temperature $\left(22 \pm 1^{\circ} \mathrm{C}\right)$ with a $12-\mathrm{h}$ light/dark cycle. Pellets of mice food without antibiotic (provided by the Animal Centre of Inner Mongolia University, Hohhot, China) were given to the mice with fresh water ad libitum. The mice were acclimatized for 2-3 days in the environment where the experiments were conducted. The animal protocol, experimental design and procedures were approved by the Inner Mongolia Agricultural University, Hohhot, China.

\section{Clinical observation and histological analysis}

The mice were monitored daily for survival and well-being status (body condition, mental state, mobility and other general conditions) (Burkholder et al. 2012). At days 0, 4, and 7, eight mice of each group were sacrificed by cervical dislocation and blood was collected by cardiac puncture. Small intestine samples were fixed in a $4 \%$ 
Table 1. The experimental design of study of the effect of S2 on mice challenged with $E$. coli O8.

\begin{tabular}{ll}
\hline Group & Experimental design \\
\hline NC group & Each mouse received $0.2 \mathrm{ml}$ sterile phosphate buffer solution (PBS) by gavage for $7 \mathrm{~d}$, once a day. \\
PC group & $\begin{array}{l}\text { Each mouse received } \mathrm{PBS} \text { as the } \mathrm{NC} \text { group and was administered intraperitoneally a } 0.3 \mathrm{ml} 50 \% \\
\text { lethal dose }\left(\mathrm{LD}_{50}\right) \text { of } E \text {. coli } \mathrm{O} 8 \text { suspension }\left(4.7 \times 10^{9} \text { colony-forming unit }(\mathrm{CFU}) / \mathrm{ml} \text { at } 4 \mathrm{~d} \text {. }\right.\end{array}$ \\
S2 group & $\begin{array}{l}\text { Each mouse received } 0.2 \mathrm{ml} \text { sterile PBS with } 2500 \mathrm{mg} / \mathrm{kg} \text { of b.w. S2 by gavage for } 7 \mathrm{~d} \text {, once } \\
\text { a day, and was administered intraperitoneally a } 0.3 \mathrm{ml} \mathrm{LD} \mathrm{LD}_{50} \text { of } E \text {. coli } \mathrm{O} 8 \text { suspension at } 4 \mathrm{~d} .\end{array}$ \\
\hline
\end{tabular}

$\mathrm{NC}$ - negative control, PC - positive control, S2 - antibacterial compound of S. cerevisiae extracted at pH 2.0

buffered formalin solution, dehydrated, cleared, embedded in paraffin, cut into $5 \mu \mathrm{m}$ thick sections, stained by haematoxylin and eosin (HE), and taken for histological analysis (Generoso et al. 2010).

\section{Immunoglobulin determination}

Some blood was allowed to clot at room temperature for $1 \mathrm{~h}$ before being centrifuged at $1500 \mathrm{r} / \mathrm{min}$ at $5{ }^{\circ} \mathrm{C}$ for $10 \mathrm{~min}$. The serum was collected and stored in aliquots at $-20^{\circ} \mathrm{C}$. Enzyme-linked immunosorbent assay (ELISA) kits (Boerdi, Nanjing, China) were used according to the manufacturer's protocol for determination of immunoglobulins A (IgA), G (IgG), and M (IgM) (Lee et al. 2006).

\section{Lymphocyte subsets Assay}

Blood was also collected in anticoagulative tubes. Aliquots of $200 \mu \mathrm{l}$ blood were added to $5 \mathrm{ml}$ haemolysin at $\times 10$ dilution, shaken, left to stand for $12 \mathrm{~min}$, then centrifuged $(310 \times \mathrm{g}, 7 \mathrm{~min})$. Lymphocyte sediments were washed with PBS $\times 3$ and suspended in $100 \mu \mathrm{lBS}$ at a concentration of $1 \times 10^{6}$ cells $/ \mu$ l. Lymphocyte suspensions were divided into two $50 \mu \mathrm{l}$ parts and transferred into a polystyrene round-bottom tube. Monoclonal rat anti-mouse CD3:FITC/CD8:PE, and monoclonal rat anti-mouse CD4:PE/CD19:FITC were added to the respective tubes. The sample was gently mixed and incubated at $4{ }^{\circ} \mathrm{C}$ for $30 \mathrm{~min}$, and then centrifuged $(310 \times \mathrm{g}, 7 \mathrm{~min})$. Lymphocytes were suspended in $300 \mu \mathrm{lPBS}$, and then analyzed by Facsealibur flow cytometer (Becton, Dickinson and Company, NewYork, USA). Lymphocyte percentages and CD4+/CD8+ were determined and calculated.

Thymus and spleen index assay

Thymus and spleen were quickly removed. Weighed indexes were calculated as follows: thymus index $=$ thymus weight/body weight; spleen index = spleen weight/body weight (Guo et al. 2012).

Caecal microflora determination

Mice caecum was weighed and digesta aseptically collected in sterilized tubes, gradient diluted $\times 10$ with sterile saline to obtain $10^{-1}-10^{-8}$ multiple of the original solution. Then aliquots of $50 \mu \mathrm{l}$ of each dilute solution were spread onto each BBL agar (selective culture medium of Bifidobacteria), LBS agar (selective culture medium of Lactobacilli), DHL agar (selective culture medium of E. coli), KF agar (selective culture medium of Enterococcus) and incubated as follows: after $48 \mathrm{~h}$ incubation at $37^{\circ} \mathrm{C}$ under anaerobic conditions, Bifidobacteria colonies grown on BBL were round, raised, and creamy with neat and smooth edge; after $48 \mathrm{~h}$ incubation at $37^{\circ} \mathrm{C}$ in anaerobic condition, Lactobacilli colonies grown on LBS agar were white and raised; after $24 \mathrm{~h}$ incubation at $37^{\circ} \mathrm{C}$, E. coli colonies grown on DHL agar were peach coloured; after $48 \mathrm{~h}$ incubationat $37^{\circ} \mathrm{C}$, Enterococcus colonies on $\mathrm{KF}$ agar were darkled and shiny with a neat edge. All bacteriological media were supplied by Hope Bio-Technology co., LTD, Qingdao, China. When the colonies appeared, appropriate dilutions were selected for counting. The visible counts per gram of caecum digesta were calculated and expressed as follows: caecal microflora counts

$(\lg \mathrm{cfu} / \mathrm{g})=\lg [\mathrm{X} / 0.05 \times$ dilution times/caecum digesta $(\mathrm{g})]$,

where $\mathrm{X}$ equals the visible counts in the appropriate dilutions.

Statistical analysis

All data were expressed as mean \pm standard deviation (SD). Differences between groups were evaluated by one-way analysis of variance (ANOVA) of SAS following a complete random design, with the group used as the experimental unit for analysis. When the system treatment was significant $(P<0.05)$, the means were compared using Duncan's multiple comparison procedure.

\section{Results}

\section{Clinical symptoms and histology of pathological changes}

Mice in the NC group had no obvious changes. After being challenged with E. coli O8 for $0.5 \mathrm{~d}$, some mice in the PC group showed signs of depression and clustering. After 
being challenged with $E$. coli $\mathrm{O} 8$ for $1-1.5 \mathrm{~d}$, mice in the $\mathrm{PC}$ group had obvious changes: narrowed eyes, diarrhoea, anorexia, depression, slow movement, clustering, and some mortality. After being challenged with $E$. coli $\mathrm{O} 8$ for $2-3$ d, the number of dead mice in the PC group increased, but the surviving mice were more vigorous and nimble than before. The number of dead mice in the S2 group was lower than in the PC group, and the eyes of the mice in the S2 group were brighter, and the mice showed more vigorous and nimble activity than those in the PC group (Table 2).

Table 2. The survival rates of mice challenged with E. coli $\mathrm{O} 8$ (\%).

\begin{tabular}{lccrrrrr}
\hline Group & $0 \mathrm{~d}$ & $0.5 \mathrm{~d}$ & $1 \mathrm{~d}$ & $1.5 \mathrm{~d}$ & $2 \mathrm{~d}$ & $2.5 \mathrm{~d}$ & $3 \mathrm{~d}$ \\
\hline NC group & 100 & 100 & 100 & 100 & 100 & 100 & 100 \\
PC group & 100 & 100 & 80 & 80 & 70 & 50 & 50 \\
S2 group & 100 & 100 & 100 & 90 & 90 & 90 & 90 \\
\hline
\end{tabular}

$\mathrm{NC}$ - negative control, PC - positive control, S2 - antibacterial compound of S. cerevisiae extracted at pH 2.0

Intestinal villi of mice in the NC group were aligned and slender (Plate XI, Fig. 1). The small intestines of mice in the PC group exhibited histologically pathological changes, shortened intestinal villi, wider intervillous spaces compared to the NC group, with some villi broken off. Intestinal villi in the $\mathrm{S} 2$ group were more slender compared to the $\mathrm{NC}$ group at $4 \mathrm{~d}$ and they also showed fewer histologically pathological changes at $7 \mathrm{~d}$ compared to the $\mathrm{PC}$ group. These results demonstrate that a challenge with $E$. coli $\mathrm{O} 8$ results in changes in the small intestine which can be reversed as in the S2 treatment.

\section{Immunoglobulins}

IgA in the PC group was significantly lower than in the $\mathrm{NC}$ group at $7 \mathrm{~d}(P<0.05)$ (Table 3). IgA, IgG, and IgM in the S2 group were significantly higher than in the NC group at $4 \mathrm{~d}(P<0.05)$. IgG and IgM in the $\mathrm{S} 2$ group was significantly higher than in the NC group at $7 \mathrm{~d}(P<0.05)$. This suggests that the IgA decreased after mice were challenged with $E$. coli $\mathrm{O} 8$ but $\mathrm{S} 2$ could reverse this phenomenon.

Table 3. Effect of S2 on immunoglobulins of mice challenged with pathogenic E. coli $\mathrm{O} 8(\mu \mathrm{g} / \mathrm{ml})$.

\begin{tabular}{lcccc}
\hline $\begin{array}{l}\text { Immuno- } \\
\text { globulin }\end{array}$ & Time & \multicolumn{3}{c}{ Group } \\
\cline { 2 - 5 } IgA & $0 \mathrm{~d}$ & $83.08 \pm 0.64$ & $\mathrm{PC}$ & $\mathrm{S} 2$ \\
\hline & $4 \mathrm{~d}$ & $83.29 \pm 0.42^{\mathrm{b}}$ & $82.87 \pm 1.70$ & $82.87 \pm 0.42$ \\
& $7 \mathrm{~d}$ & $84.77 \pm 0.64^{\mathrm{a}}$ & $83.71 \pm 1.27^{\mathrm{b}}$ & $93.25 \pm 1.06^{\mathrm{a}}$ \\
$\mathrm{IgG}$ & $0 \mathrm{~d}$ & $116.59 \pm 0.90$ & $74.17 \pm 1.48^{\mathrm{b}}$ & $87.95 \pm 0.42^{\mathrm{a}}$ \\
& $4 \mathrm{~d}$ & $116.89 \pm 1.19^{\mathrm{b}}$ & $116.29 \pm 1.79$ & $115.10 \pm 1.19$ \\
& $7 \mathrm{~d}$ & $117.19 \pm 0.30^{\mathrm{b}}$ & $117.19 \pm 3.29^{\mathrm{b}}$ & $134.81 \pm 0.60^{\mathrm{a}}$ \\
$\mathrm{IgM}$ & $0 \mathrm{~d}$ & $309.17 \pm 3.01$ & $112.41 \pm 2.69^{\mathrm{b}}$ & $132.12 \pm 2.09^{\mathrm{a}}$ \\
& $4 \mathrm{~d}$ & $305.55 \pm 4.21^{\mathrm{b}}$ & $310.37 \pm 1.81$ & $313.98 \pm 9.03$ \\
& $7 \mathrm{~d}$ & $306.76 \pm 5.42^{\mathrm{b}}$ & $309.17 \pm 13.84^{\mathrm{b}}$ & $396.41 \pm 18.05^{\mathrm{a}}$ \\
\end{tabular}

Values with different lowercase superscripts in the same row mean a significant difference $(P<0.05)$; values with the same or no superscript mean no significant difference $(P>0.05)$.

$\mathrm{NC}$ - negative control, PC - positive control, S2 - antibacterial compound of $S$. cerevisiae extracted at $\mathrm{pH} 2.0$

Lymphocyte subsets

$\mathrm{CD} 3+$ of mice in the S2 group was significantly higher than in the NC group at $7 \mathrm{~d}$ $(P<0.05)$ (Table 4, Plate XI, Fig. 2). CD8+ of mice in the S2 group was significantly 
lower than in NC group at $7 \mathrm{~d}(P<0.05)$. This suggests that lymphocyte subsets show no obvious changes after mice are challenged with $E$. coli O8, but after S2 treatment $\mathrm{CD} 3+$ could increase, and CD8+ decrease.

Table 4. Effect of S2 on lymphocyte subsets of mice challenged with pathogenic E. coli O8 (\%).

\begin{tabular}{|c|c|c|c|c|}
\hline \multirow{2}{*}{ Lymphocyte } & \multirow{2}{*}{ Time } & \multicolumn{3}{|c|}{ Group } \\
\hline & & $\mathrm{NC}$ & $\mathrm{PC}$ & $\mathrm{S} 2$ \\
\hline \multirow[t]{3}{*}{ CD3+ } & $0 \mathrm{~d}$ & $40.06 \pm 1.27$ & $40.13 \pm 2.18$ & $40.07 \pm 1.19$ \\
\hline & $4 d$ & $40.13 \pm 3.14$ & $40.46 \pm 2.47$ & $44.01 \pm 2.55$ \\
\hline & $7 \mathrm{~d}$ & $39.23 \pm 3.79^{b}$ & $39.22 \pm 1.24^{\mathrm{b}}$ & $50.88 \pm 1.24^{\mathrm{a}}$ \\
\hline \multirow[t]{3}{*}{ CD4+ } & $0 \mathrm{~d}$ & $36.25 \pm 0.85$ & $36.43 \pm 0.49$ & $36.30 \pm 0.91$ \\
\hline & $4 \mathrm{~d}$ & $36.35 \pm 0.94$ & $36.41 \pm 0.80$ & $36.62 \pm 2.29$ \\
\hline & $7 \mathrm{~d}$ & $36.28 \pm 2.06$ & $36.17 \pm 5.87$ & $36.81 \pm 4.09$ \\
\hline \multirow[t]{3}{*}{ CD8+ } & $0 \mathrm{~d}$ & $25.57 \pm 3.43$ & $25.31 \pm 2.89$ & $25.26 \pm 3.42$ \\
\hline & $4 \mathrm{~d}$ & $25.60 \pm 4.86$ & $25.50 \pm 1.86$ & $19.58 \pm 2.55$ \\
\hline & $7 \mathrm{~d}$ & $25.70 \pm 1.32^{\mathrm{a}}$ & $26.69 \pm 0.59^{\mathrm{a}}$ & $18.59 \pm 2.79^{b}$ \\
\hline \multirow[t]{3}{*}{$\mathrm{CD} 4+/ \mathrm{CD} 8+$} & $0 \mathrm{~d}$ & $1.45 \pm 0.21$ & $1.46 \pm 0.16$ & $1.46 \pm 0.18$ \\
\hline & $4 \mathrm{~d}$ & $1.47 \pm 0.29$ & $1.43 \pm 0.10$ & $1.90 \pm 0.25$ \\
\hline & $7 \mathrm{~d}$ & $1.42 \pm 0.13$ & $1.36 \pm 0.23$ & $2.06 \pm 0.55$ \\
\hline \multirow[t]{3}{*}{ CD19+ } & $0 \mathrm{~d}$ & $11.85 \pm 1.22$ & $11.93 \pm 1.04$ & $11.88 \pm 1.05$ \\
\hline & $4 \mathrm{~d}$ & $11.95 \pm 1.12$ & $11.77 \pm 2.77$ & $12.19 \pm 2.40$ \\
\hline & $7 \mathrm{~d}$ & $12.06 \pm 3.94$ & $11.84 \pm 4.37$ & $12.53 \pm 2.59$ \\
\hline
\end{tabular}

Values with different lowercase superscripts in the same row mean a significant difference $(P<0.05)$; values with the same or no superscript mean no significant difference $(P>0.05)$.

$\mathrm{NC}$ - negative control, PC - positive control, S2 - antibacterial compound of $S$. cerevisiae extracted at $\mathrm{pH} 2.0$

Thymus and spleen indexes

Thymus indexes of mice in the $\mathrm{PC}$ group were significantly lower than in the $\mathrm{NC}$ group at $7 \mathrm{~d}(P<0.05)$ (Table 5). Spleen indexes of mice in the S2 group were significantly higher than in the NC group at $7 \mathrm{~d}(P<0.05)$. This suggests that thymus indexes decrease after mice are challenged with $E$. coli $\mathrm{O} 8$, but $\mathrm{S} 2$ could reverse this phenomenon.

Table 5. Effects of S2 on the thymus index and spleen index of mice challenged with pathogenic E. coli O8.

\begin{tabular}{lcccc}
\hline \multirow{2}{*}{ Index } & Time & \multicolumn{3}{c}{ Group } \\
\cline { 3 - 4 } & & NC & PC & S2 \\
\hline Spleen index & $0 \mathrm{~d}$ & $5.63 \pm 0.52$ & $5.59 \pm 0.89$ & $5.57 \pm 0.28$ \\
& $4 \mathrm{~d}$ & $5.71 \pm 1.48$ & $5.75 \pm 1.70$ & $6.89 \pm 1.52$ \\
Thymus index & $7 \mathrm{~d}$ & $5.83 \pm 1.72^{\mathrm{b}}$ & $5.40 \pm 0.35^{\mathrm{b}}$ & $10.16 \pm 2.89^{\mathrm{a}}$ \\
& $0 \mathrm{~d}$ & $2.64 \pm 0.49$ & $2.60 \pm 0.31$ & $2.60 \pm 0.17$ \\
& $4 \mathrm{~d}$ & $2.78 \pm 0.67$ & $2.70 \pm 0.52$ & $3.00 \pm 0.49$ \\
\hline
\end{tabular}

Values with different lowercase superscripts in the same row mean a significant difference $(P<0.05)$; values with the same or no superscript mean no significant difference $(P>0.05)$.

$\mathrm{NC}$ - negative control, PC - positive control, S2 - antibacterial compound of S. cerevisiae extracted at $\mathrm{pH} 2.0$

\section{Caecal microflora}

E. coli in the $\mathrm{PC}$ group were significantly higher than in the $\mathrm{NC}$ group at $7 \mathrm{~d}(P<0.05)$, and Bifidobacteria were significant lower. Bifidobacteria in the S2 group were significant lower than in the $\mathrm{NC}$ group at $7 \mathrm{~d}(P<0.05)$ (Table 6). This suggests that $E$. coli increase and 
Bifidobacteria decrease after mice are challenged with $E$. coli O8, but S2 could decrease $E$. coli and increase Bifidobacteria of mice challenged with E. coli O8.

Table 6. Effect of S2 on caecal microflora of mice challenged with pathogenic E. coli O8 (lg CFU/g of caecum wet weight).

\begin{tabular}{lcccc}
\hline \multirow{2}{*}{ Bacteria } & Time & NC & Group & SC \\
\cline { 3 - 5 } & & $6.85 \pm 0.88$ & $6.82 \pm 0.01$ & $6.81 \pm 0.24$ \\
\hline E. coli & $0 \mathrm{~d}$ & $6.87 \pm 0.85$ & $6.86 \pm 0.79$ & $6.07 \pm 1.29$ \\
& $4 \mathrm{~d}$ & $6.83 \pm 0.84^{\mathrm{b}}$ & $10.05 \pm 0.14^{\mathrm{a}}$ & $6.47 \pm 0.64^{\mathrm{b}}$ \\
Enterococcus & $7 \mathrm{~d}$ & $6.60 \pm 0.32$ & $6.55 \pm 0.14$ & $6.66 \pm 0.05$ \\
& $0 \mathrm{~d}$ & $6.53 \pm 0.24$ & $6.55 \pm 0.74$ & $5.40 \pm 0.36$ \\
Lactobacillus & $4 \mathrm{~d}$ & $6.64 \pm 0.26$ & $6.56 \pm 0.74$ & $5.25 \pm 0.55$ \\
& $7 \mathrm{~d}$ & $6.11 \pm 0.06$ & $6.09 \pm 0.15$ & $6.12 \pm 0.30$ \\
Bifidobacterium & $0 \mathrm{~d}$ & $6.10 \pm 0.23$ & $6.06 \pm 0.14$ & $6.35 \pm 0.97$ \\
& 4d & $6.17 \pm 0.04$ & $5.58 \pm 0.55$ & $5.83 \pm 0.78$ \\
& $7 \mathrm{~d}$ & $10.02 \pm 0.05$ & $10.01 \pm 0.03$ & $9.98 \pm 0.05$ \\
& $7 \mathrm{~d}$ & $10.03 \pm 0.30$ & $10.00 \pm 0.57$ & $10.17 \pm 0.26$ \\
& $7 \mathrm{~d}$ & $10.17 \pm 0.21^{\mathrm{a}}$ & $6.62 \pm 0.23^{\mathrm{c}}$ & $8.16 \pm 0.53^{\mathrm{b}}$ \\
\hline
\end{tabular}

Values with different lowercase superscripts in the same row mean a significant difference $(P<0.05)$; values with the same or no superscript mean no significant difference $(P>0.05)$.

$\mathrm{NC}$ - negative control, PC - positive control, S2 - antibacterial compound of $S$. cerevisiae extracted at pH 2.0

\section{Discussion}

Live yeast ( $S$. cerevisiae) is an important probiotic that has been reported to modulate the intestinal microbial balance (Haldar et al. 2011), to improve humoral immune responses, intestinal structure, and function of animals (Haldar et al. 2011; Xiong et al. 2015). Furthermore, live yeast supplementation was shown to mitigate bacteria-associated immunological derangement and intestinal disorders in pigs (Trevisi et al. 2015) and to attenuate pathogen-induced intestinal inflammation in mice (Jawhara et al. 2012). Similar results were also found in in vitro studies, where treatment with live yeast reduced the expressions of pro-inflammatory cytokines and increased the expressions of antiinflammatory cytokines of porcine intestinal epithelial cells following bacterial invasion (Zanello et al. 2011). Nevertheless, a comprehensive understanding of antibacterial compounds produced by yeasts in the metabolism is lacking. Moreover, the physiological activity of yeast is easily affected by the processing technology, storage, culture medium, temperature, $\mathrm{pH}$, internal environment of digestive tract and feeding pattern. So, the stability of yeast is poor yielding unstable effects. The antibacterial compound produced by yeast, on the other hand, may retain its quality and therefore the effect may be stable.

Some yeasts can produce antibacterial substances like organic acids and killer toxins, the variety and quantity depending on the source and species of yeast (Csoma et al. 2010; Lane et al. 2011). Koumiss has beneficial effects, therefore, the antibacterial effects of various organic acids and killer toxins contained in antibacterial compounds of $S$. cerevisiae from koumiss named S2 were studied.

Mice appeared anorexic and exhibited other pathological changes after they were challenged with $E$. coli $\mathrm{O} 8$ in the PC group, similar to the clinical symptoms of mice challenged with E. coli O157:H7 (Fan et al. 2012; Bian et al. 2016). Bian et al. (2016) found that mice had diarrhoea after they were challenged with E. coli O157:H7, however, Fan et al. (2012) reported that mice had no diarrhoea after they were challenged with 
E. coli $\mathrm{O} 157: \mathrm{H} 7$. This might be due to the differences of source, serotype, virulence factor, and infection method (injection or gavage) of $E$. coli. Moreover, we found that the intestinal villi of mice were damaged after they were challenged with $E$. coli O8. This was consistent with Girard et al. (2008). But S2 could relieve the clinical symptoms and improve the condition of the small intestine of mice challenged with E. coli O8. A possible mechanism is that S2 could preserve the intestinal mucosal integrity and permeability, which are affected during pathological and infectious episodes.

Immunoglobulins are the primary antibodies mediating humoral immunity; antibody levels in serum reflect to a certain degree the body's resistibility to disease. IgA, IgG, and IgM represent immunoglobulin concentrations in serum (Fan et al. 2012). The results of our study demonstrated that IgA decreased after the mice were challenged with $E$. coli O8. However, S2 could increase immunoglobulin levels after mice were challenged with E. coli $\mathrm{O} 8$. IgA, IgG, and $\mathrm{IgM}$ in the $\mathrm{S} 2$ group were significantly higher than in the $\mathrm{NC}$ group at $4 \mathrm{~d}$. IgG and IgM in the S2 group were significantly higher than in the NC group at $7 \mathrm{~d}$. It is considered that S2 could relieve clinical symptoms of mice challenged with $E$. coli $\mathrm{O} 8$, recovering some indexes to normal levels. It is suggested that $\mathrm{S} 2$ is beneficial to the improving of humoral immune ability of mice challenged with $E$. coli O8, enhancing the immune function, and inducing anti-inflammatory immune effects.

The $\mathrm{T}$ and $\mathrm{B}$ lymphocytes participate in cell immunity functions. Levels of CD3+ represent total $\mathrm{T}$ cell levels in peripheral lymphoid organs. A decrease in CD3+ signals a reduction of mature $\mathrm{T}$ cells, resulting in the decrease of immunity function. T lymphocytes contain CD4+ and CD8+ cells. Higher levels of CD4+ and the value of CD4+/CD8+ within limits demonstrates a better immunity function (Sharpe and Abbas 2006). CD19+ is a surface antigen of B lymphocytes which is expressed at an early stage, persisting till it differentiates into plasma cells (LeBien and Tedder 2008). Relatively small changes in CD19 surface expression can lead to a loss of tolerance and autoantibody production (Sato et al. 2004). The results of our study suggest that S2 could increase CD3+, and decrease $\mathrm{CD} 8+$ of mice challenged with $E$. coli $\mathrm{O} 8$. It is considered that $\mathrm{S} 2$ is beneficial to increasing the immunity function.

The thymus is the main central immune organ of lymphocyte differentiation and maturation, and the spleen is the most important peripheral lymphoid organ. Lymphocytes develop and mature in the thymus, and then they are transferred to the spleen, lymphoid tissues, and lymphoid organs by the circulatory system to store and play an immunization role. Therefore, weight increments of the thymus and spleen indicate rapid development of immune organs, and increase of thymus and spleen indexes indicates rapid maturation of immune systems (Guo et al. 2012). The results of our study suggest that thymus indexes of mice decrease after the challenge with $E$. coli O8. However, S2 could increase thymus and spleen indexes of mice challenged with $E$. coli O8, which indicates that $\mathrm{S} 2$ promotes the growth and development of the thymus and spleen, and improves the immune function of mice.

The flora in the intestinal tract is affected by the diet and the environment. The balance and stability of the intestinal flora are essential conditions determining the animal's health. The caecal microflora directly reflects changes in the intestinal flora. Anaerobes are the main bacteria in the caecum, the predominant species belonging to Bifidobacteria and Lactobacilli. Escherichia coli and Enterococcus are the conditioned pathogens within the caecum. Their numbers reflect the intestinal health (Holzapfel et al. 1998; Hooper and Gordon 2001). The results of our study suggest that when $E$. coli increase after mice are challenged with $E$. coli O8, Bifidobacteria decrease. It is considered that $E$. coli $\mathrm{O} 8$ results in dysbacteriosis in mice. It was similar to the change of intestinal flora after mice were challenged with E. coli O157:H7 (Bian et al. 2016). S2 could decrease E. coli, increase Bifidobacteria of mice challenged with $E$. coli $\mathrm{O} 8$, suggesting that $\mathrm{S} 2$ promotes the growth 
and colonization of probiotics. In addition, the acetic acid produced by Bifidobacteria and the organic acids in $\mathrm{S} 2$ could regulate the $\mathrm{pH}$ value of the intestinal tract, inhibit the growth and reproduction of harmful bacteria, maintain normal percentages of caecal microflora, and prevent diseases. S2 may promote a more symbiotic intestinal microflora favouring the host when challenged with an enteric pathogen such as E. coli.

In conclusion, mice challenged with $E$. coli $\mathrm{O} 8$ displayed histologically pathological changes in the small intestine, an increase in E. coli, thymus indexes, and IgA, and a decrease in Bifidobacteria. The culture extract of $S$. cerevisiae (S2) could relieve and improve small intestine symptoms, increase spleen indexes, IgG, IgM, and CD3+, decrease $\mathrm{CD} 8+$ in mice challenged with $E$. coli $\mathrm{O} 8$. So, the $\mathrm{S} 2$ can enhance the immune function in mice, and influence their caecal microflora. The study provides a theoretical foundation for utilizing an antibacterial compound of $S$. cerevisiae from koumiss for therapeutic purposes.

\section{Acknowledgements}

This work was supported by the National Key Technologies R\&D Program (2015BAD03B04-5), National Natural Science Foundation of China (CN) (31260570), Higher Educational Scientific Research Projects of Inner Mongolia Autonomous Region (NJZY 18065), and the Science and Technology Innovation Projects of Vocational and Technical College of Inner Mongolia Agricultural University (2017CXTD02). We also thank Dr. Mark Goettel formerly of the Lethbridge Research Centre of Agriculture \& Agri-Food, Canada for revising the manuscript.

\section{References}

Bian X, Wang TT, Xu M, Evivie SE, Luo GW, Liang HZ, Yu SF, Huo GC 2016: Effect of Lactobacillus strains on intestinal microflora and mucosa immunity in Escherichia coli O157:H7-induced diarrhea in mice. Curr Microbiol 73: 65-70

Boerlin P, McEwen SA, Boerlin-Petzold F, Wilson JB, Johnson RP, Gyles CL 1999: Associations between virulence factors of Shiga toxin-producing Escherichia coli and disease in humans. J Clin Microbiol 37: 497-503

Burkholder T, Foltz C, Karlsson E, Linton CG, Smith JM 2012: Health evaluation of experimental laboratory mice. Curr Protoc Mouse Biol 2: 145-165

Chen YJ, Aorigele C, Wang CJ, Simujide H, Yang SQ 2015: Screening and extracting mycocin secreted by yeast isolated from Koumiss and their antibacterial effect. J Food Nutr Res 3: 52-56

Chen YJ, Wang CJ, Hou WQ, Wang XS, Gali BG, Simujide H, Yang SQ, Aqima W, Zhao YF, Wu YG, Aorigele C 2017: Effects of antibacterial compound produced by Saccharomyces cerevisiae in Koumiss on pathogenic Escherichia coli O8 and its cell surface characteristics. J Integr Agr 16: 742-748

Chiquette J 2009: Evaluation of the protective effect of probiotics fed to dairy cows during a subacuteruminal acidosis challenge. Anim Feed Sci Tech 153: 278-291

Cizman M 2003: The use and resistance to antibiotics in the community. Int J Antimicrob Agents 21: 297-307

Csoma H, Zakany N, Capece A, Romano P, Sipiczki M 2010: Biological diversity of Saccharomyces yeasts of spontaneously fermenting wines in four wine regions: comparative genotypic and phenotypic analysis. Int J Food Microbiol 140: 239-248

Dwivedi GR, Maurya A, Yadav DK, Khan F, Darokar MP, Srivastava KS 2015: Drug resistance reversal potential of ursolic acid derivatives against nalidixic acid- and multidrug-resistant Escherichia coli. Chem Biol Drug Des 86: 272-283

Etienne-Mesmin L, Livrelli V, Privat M, Denis S, Cardot JM, Alric M, Blanquet-Diot S 2011: Effect of a new probiotic Saccharomyces cerevisiae strain on survival of Escherichia coli O157:H7 in a dynamic gastrointestinal model. Appl Environ Microbiol 77: 1127-1131

Fan HY, Wang L, Luo J, Long BG 2012: Protection against Escherichia coli O157:H7 challenge by immunization of mice with purified Tir proteins. Mol Biol Rep 39: 989-997

Generoso SV, Viana M, Santos R, Martins FS, Machado JA, Arantes RM, Nicoli JR, Correia MI, Cardoso VN 2010: Saccharomyces cerevisiae strain UFMG 905 protects against bacterial translocation, preserves gut barrier integrity and stimulates the immune system in a murine intestinal obstruction model. Arch Microbiol 192: $477-484$

Girard F, Frankel G, Phillips AD, Cooley W, Weyer U, Dugdale AHA, Woodward MJ, La Ragione RM 2008: Interaction of enterohemorrhagic Escherichia coli O157: H7 with mouse intestinal mucosa. FEMS Microbiol Lett 283: 196-202

Gow SP, Waldner CL, Harel J, Boerlin P 2008: Associations between antimicrobial resistance genes in fecal generic Escherichia coli isolates from cow-calf herds in western Canada. Appl Environ Microbiol 74: 3658-3666 
Guo L, Sun YL, Wang AH, Xu CE, Zhang MY 2012: Effect of polysaccharides extract of rhizoma- atractylodis macrocephalae on thymus, spleen and cardiac indexes, caspase-3 activity ratio, Smac/DIABLO and HtrA2/Omi protein and mRNA expression levels in aged rats. Mol Biol Rep 39: 9285-9290

Haldar S, Ghosh TK, Toshiwati, Bedford MR 2011: Effects of yeast (Saccharomyces cerevisiae) and yeast protein concentrate on production performance of broiler chickens exposed to heat stress and challenged with Salmonella enteritidis. Anim Feed Sci Technol 168: 61-71

Holzapfel WH, Haberer P, Snel J, Schillinger U, Huis in't Veld JH 1998: Overview of gut flora and probiotics. Int J Food Microbiol 41: 85-101

Hooper LV, Gordon JI 2001: Commensal host-bacterial relationships in the gut. Science 292: 1115-1118

Ishii S, Konagaya Y 2002: Beneficial role of koumiss intake of Mongolian Nomads. J Jpn Soc Nutr Food Sci 55: 281-285

Jawhara S, Habib K, Maggiotto F, Pignede G, Vandekerckove P, Maes E, Dubuquoy L, Fontaine T, Guerardel Y, Poulain D 2012: Modulation of intestinal inflammation by yeasts and cell wall extracts: strain dependence and unexpected anti inflammatory role of glucan fractions. Plos One 7: e40648

Lane MM, Burke N, Karreman R, Wolfe KH, O’Byrne CP, Morrissey JP 2011: Physiological and metabolic diversity in the yeast Kluyveromyces marxianus. Antonie Van Leeuwenhoek 100: 507-519

LeBien TW, Tedder TF 2008: B lymphocytes: how they develop and function. Blood 112: 1570-1580

Lee JS, Poo H, Han DP, Hong SP, Kim K, Cho MW, Kim E, Sung MH, Kim CJ 2006: Mucosal immunization with surface-displayed severe acute respiratory syndrome coronavirus spike protein on Lactobacillus casei induces neutralizing antibodies in mice. J Virol 80: 4079-4087

Levy SB, Marshall B 2004: Antibacterial resistance worldwide: causes, challenges and responses. Nat Med 10: S122-S129

Mainda G, Bessell PR, Muma JB, McAteer SP, Chase-Topping ME, Gibbons J, Stevens MP, Gally DL, deC Bronsvoort BM 2015: Prevalence and patterns of antimicrobial resistance among Escherichia coli isolated from Zambian dairy cattle across different production systems. Sci Rep 5: 12439

Montanari G, Zambonelli C, Grazia L, Kamesheva GK, Shigaeva MK 1996: Saccharomyces unisporus as the principal alcoholic fermentation microorganism of traditional koumiss. J Dairy Res 63: 327-331

Mu ZS, Yang XJ, Yuan HL 2012: Detection and identification of wild yeast in Koumiss. Food Microbiol 31: 301-308

Quan S, Burentegusi, Yu B 2006: Microflora in Hurunge, traditional starter culture, from Inner Mongolia, China. Anim Sci J 77: 235-241

Sato S, Fujimoto M, Hasegawa M, Takehara K, 2004: Altered blood B lymphocyte homeostasis in systemic sclerosis: expanded naive B cells and diminished but activated memory B cells. Arthritis Rheum 50: 1918-1927

Sharpe AH, Abbas AK 2006: T-cell costimulation - biology, therapeutic potential, and challenges. N Engl J Med 355: 973-975

Simujide H, Aorigele C, Wang CJ, Li Y, Bai T 2012: Occurrence and characteristics of virulence genes of Escherichia coli strains isolated from healthy dairy cows in Inner Mongolia, China. Braz J Microbiol 43: 528-534

Swanson KS, Grieshop CM, Flickinger EA, Bauer LL, Healy HP, Dawson KA, Merchen NR, Fahey GC Jr 2002a: Supplemental fructooligosaccharides and mannanoligosaccharides influence immune function, ileal and total tract nutrient digestibilities, microbial populations and concentrations of protein catabolites in the large bowel of dogs. J Nutr 132: 980-989

Swanson KS, Grieshop CM, Flickinger EA, Healy HP, Dawson KA, Merchen NR, Fahey GC Jr 2002b: Effects of supplemental fructooligosaccharides plus mannanoligosaccharides on immune function and ileal and fecal microbial populations in adult dogs. Arch Tierernahr 56: 309-318

Tadesse DA, Zhao S, Tong E, Ayers S, Singh A, Bartholomew MJ, McDermott PF 2012: Antimicrobial drug resistance in Escherichia coli from humans and food animals, United States, 1950-2002. Emerg Infect Dis 18: 741-749

Trevisi P, Colombo M, Priori D, Fontanesi L, Galimberti G, Calò G, Motta V, Latorre R, Fanelli F, Mezzullo M, Pagotto U, Gherpelli Y, D'Inca R, Bosi P 2015: Comparison of three patterns of feed supplementation with live yeast on postweaning diarrhea, health status, and blood metabolic profile of susceptible weaning pigs orally challenged with F4ac. J Anim Sci 93: 2225-2233

Xiong X, Yang HS, Li B, Liu G, Huang RL, Li FN, Liao P, Zhang YZ, Nyachoti CM, Deng D 2015: Dietary supplementation with yeast product improves intestinal function, and serum and ileal amino acid contents in weaned piglets. Livest Sci 171: 20-27

Zanello G, Meurens F, Berri M, Chevaleyre C, Melo S, Auclair E, Salmon H 2011: Saccharomyces cerevisiae decreases inflammatory responses induced by $\mathrm{F} 4(+)$ enterotoxigenic Escherichia coli in porcine intestinal epithelial cells. Vet Immunol Immunopathol 141: 133-138 
Plate XI

Chen Y. et al.: Effect of antibacterial ... pp. 233-241

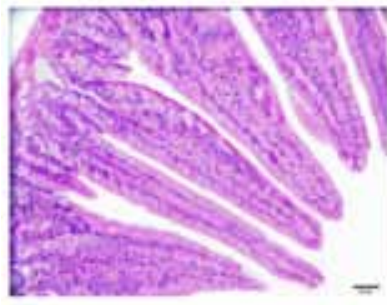

(a)

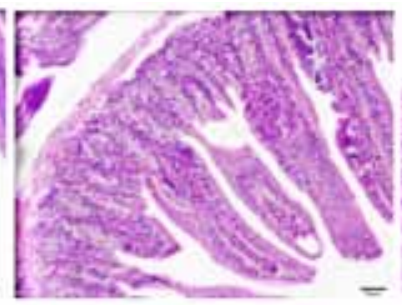

(b)

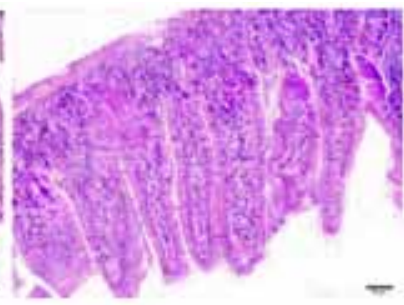

(c)

Fig. 1. Effect of $\mathrm{S} 2$ on the intestinal villi of mice challenged with pathogenic E. coli O8 (HE staining, $\times 200$ ). (a) Histological section of small intestinal villi of mice in the NC group at $7 \mathrm{~d}$. (b) Histological section of small intestinal villi of mice in PC group at $7 \mathrm{~d}$. (c) Histological section of the intestinal villi of mice in $\mathrm{S} 2$ group at $7 \mathrm{~d}$.

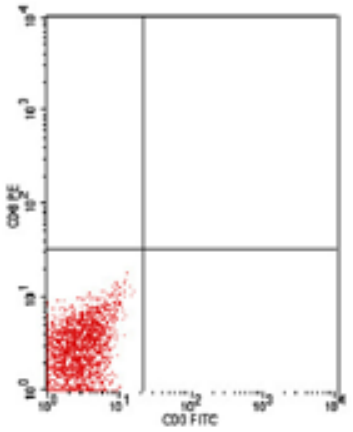

(a)

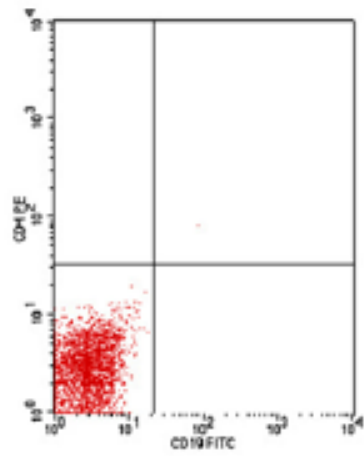

(d)

(b)

(e)

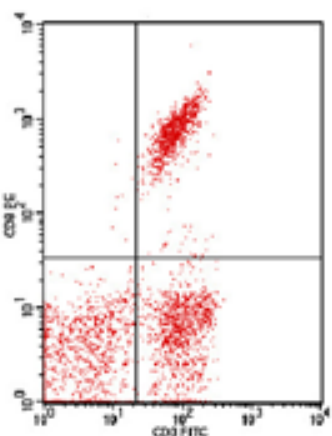

(c)
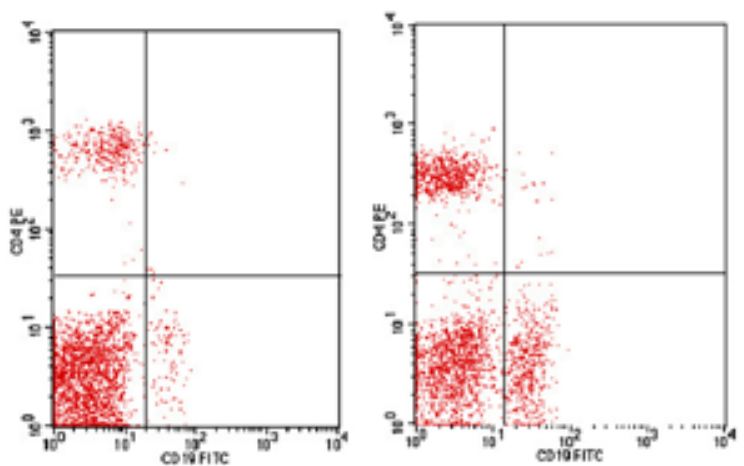
(f)

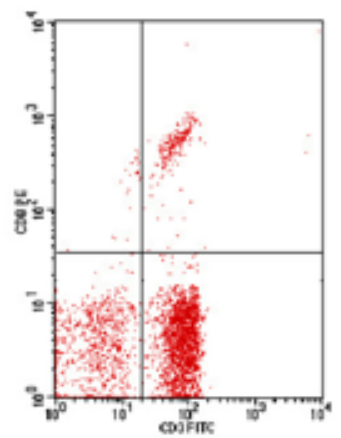

Fig. 2. Effect of $\mathrm{S} 2$ on lymphocyte subsets in serum of mice challenged with pathogenic E. coli O8. (a) $\mathrm{CD} 3+$ and $\mathrm{CD} 8+$ of $\mathrm{NC}$ group at $7 \mathrm{~d}$; (b) CD3+ and CD8+ of $\mathrm{PC}$ group at $7 \mathrm{~d}$; (c) CD3+ and CD8+ of S2 group at $7 \mathrm{~d}$; (d) CD4+ and CD19+ of NC group at $7 \mathrm{~d}$; (e) CD4+ and CD19+ of PC group at $7 \mathrm{~d}$; (f) CD4+ and CD19+ of S2 group at $7 \mathrm{~d}$. 